\title{
The role of space in the emergence and endurance of organizing: How independent workers and material assemblages constitute organization
} Boukje Cnossen and Nicolas Bencherki

\section{A more recent version was published as:}

Cnossen, B., \& Bencherki, N. (2018). The role of space in the emergence and endurance of organizing: How independent workers and material assemblages constitute organizations: Human Relations. https://doi.org/10.1177/0018726718794265

\begin{abstract}
Where do new organizations come from, and how do they persist? Based on an ethnographic study of two creative hubs in Amsterdam, in which creative independent workers rented studio space, we show how space plays a role in constituting new organizations and making them last. Focusing on challenging moments in the development of these two creative hubs, we propose that space, understood as a material assemblage, participates in providing endurance to organizing practices. It does so because space and practice reflexively account for each other. In other words, space may constrain or enable practices, and provide them with meaning, as the literature abundantly illustrates, but practices also define and shape space. Rather than emphasizing either of these two options, we argue that they should be understood as integral to each other. Furthermore, it is precisely their reflexive relation that contributes to organizing. Our study contributes to the literature on the communicative constitution of organizations, and more broadly to the knowledge of organizing in the creative industries.

\section{Keywords}

assemblage, $\mathrm{CCO}$, constitution of organization, creative industries, emergence and endurance of organizing, independent workers, organizing, practices, space
\end{abstract}




\section{Introduction}

The past years witnessed a rising interest for places accommodating freelance workers, in the creative industries and elsewhere (e.g., Gandini, 2015; Kingma, 2016; Garrett et al, 2017). This interest may be due to the increasing number of self-employed individuals throughout the world (Cappelli and Keller, 2013), as well as to a growing trend of establishing clusters of creative businesses in cities (Hitters and Richards, 2002; Musterd and Murie, 2011), made possible by the availability of former industrial buildings ready to be repurposed (Evans, 2009). While their specific missions and sizes vary (Bruneel et al., 2012; Capdevila, 2015), these hubs or clusters (Evans, 2009; Pratt, 2015) often benefit from governments support (Peck, 2012), as governments hope that such places will foster innovation (Capdevila, 2015; Gandini, 2015) and regional development (Mould \& Comunian, 2015).

In what may appear as a contradiction, there has also been a growing interest for "nomadism" in and out of organizations (Kociatkiewicz and Kostera, 2015). "Knowledge nomads" are described as committed organizational members (Pittinsky and Shih, 2004), and mobile work, or mobility for work, in fact concerns not only white-collar workers, but all strands of society (Cohen, 2010). Metaphors of movement and of "liquidity, flows, fluidity" abound in organization studies and management journals (Costas, 2013). Yet, contrary to popular belief, we know that knowledge workers are not the largest category of mobile workers (Ojala and Pyöriä, 2017), nor are mobile workers and so-called "hot-deskers" completely abstracted from their place of work, as they still need to set-up their immediate environment, as ephemeral as it may be (Brown and O’Hara, 2003).

Research on the relation between practice and space therefore seems to favour two apparently contradictory lines of argument: either organizational spaces matter (in both senses of 
the word) in fostering work and organizing practices, to the point that we must offer workers new places for their work if needed; or practices have become so fluid that they transcend location (in part at least thanks to technology). Both strands of literature, though, assume a relation between organizing and spatiality, whether by insisting on the importance of space, or by suggesting that technology reconfigures it. The apparent tension between both positions raises an important question: Why are we unable to fully untether organizing from space?

The answer may have to do with the intrinsic interconnectedness between organizing and space. We know that work on the street or in a car still requires workers, such as cops (Manning and Van Maanen, 1978), paramedics (Corman, 2017), sanitation workers (Nagle, 2013), or outreach workers (Smith and Anderson, 2018), to deal with space. How could Kafka criticize administrative absurdity in The Castle, and how could Bulgakov offer a satire of communist bureaucracy in Diaboliad, without having their protagonists wander from office to office, through endless successions of corridors? Would Chaplin's Modern Times be as powerful, if the director's alter ego had not been carried through the industrial machine's seemingly unending series of cogs? State power relates to the way its network of archives and offices is spatially distributed (Dean and Massumi, 1992; Vismann, 2008), and the same could be said of many organizations and businesses. The organization of the first Jesuits was spatially structured, radiating from Rome to the Provinces, and to each College, where a spatial arrangement could be found again (Quattrone, 2004). More pedestrian and small-scale organizational efforts, such as the production and delivery of food in restaurants, are spatially distributed, with several stations in the kitchen and waiters attending to different sections in the dining room (Sutton et al., 2004). Similarly, in hospitals, mobile robots and radio-frequency identification (RFID) tags help 
simplify healthcare coordination across space (Bloss, 2011; Ozkil et al., 2009). In short, there is no organizing without space.

To understand the intimate interweaving of space and organizing, we turn to the literature studying how practice constitutes organizations. Attention to practice reveals, for instance, how routines are created and maintained (Feldman and Orlikowski, 2011), how legitimacy is achieved (De Vaujany and Vaast, 2014), how learning and knowing are enabled (Gherardi, 2000), or even how industries can be "moral" (Anteby, 2010). If we are willing to accept that organizations emerge from practice, the question then becomes: if there is no organizing without space, how do practices consolidate the relation between the two?

We align with a tradition within practice theories that is known as the communicative constitution of organization (CCO). It proposes that practice weaves together singular settings into a continuous organizational landscape, by moving action through time and space (Cooren et al., 2005; Vásquez and Cooren, 2013; Vásquez, 2016). CCO studies focus on the role of discourse in constituting organizations (e.g., Taylor and Van Every, 2000; McPhee, 2004; Grant et al., 2005; Schoeneborn, 2011), but also recognize the part of materiality in the constitutive process. Documents, blackboards, sticks, measuring instruments and other artefacts can all contribute to the durability of organizations (Cooren, 2004; Brummans, 2007; Cooren and Bencherki, 2010; Cooren and Matte, 2010; Bencherki, 2016).

We extend this literature to show that endurance is not only attributable to single artefacts, but also to the way they form assemblages (Duff and Sumartojo, 2017). We understand these assemblages (Venn, 2006; Phillips, 2006) as organizational in nature. Relative properties reveal themselves when artefacts are considered as assemblage, such centrality and marginality, malleability and firmness, mobility and fixity, and so forth. These properties may then help in 
making practices durable (Czarniawska, 2005; Sillince, 2010; Czarniawska 2013; Dobusch and Schoeneborn, 2015). Thee full semantic range of the notion of space, we suggest, is better capture when thinking of it as an organizational assemblage.

Thus, our study's central question takes on yet another formulation: How does space as assemblage contribute to the endurance of organizational practices? The question is tackled by observing two temporary creative hubs for artists and other professionals. Creative hubs provide inexpensive studios to (mostly self-employed) workers and offer an opportunity to study the link between space and organizing practice, as they face a unique paradox. On the one hand, they offer some of the services and amenities organizations typically provide - common areas for socialization and collaboration, copiers, coffee, and so forth - in the hope that users share knowledge or cooperate across their respective projects (Bøllingtoft, 2012; Pauwels et al, 2016). Yet, users of such creative hubs precisely do not want a traditional work environment. Hence, creative hubs must balance the need to integrate their members and offer them services they need, against the risk of becoming conventional organizations.

Growing attention is given to what happens within creative hubs, thus considering space as a pre-existing container for practice. However, creative hubs are often temporary, and their users' economic reality is often precarious (Avdikos and Kalogeresis, 2016), which makes their endurance a particularly relevant question. While these are not always (formal) organizations, in all cases they display some degree of "organizationality" (Dobusch and Schoeneborn, 2015), and may be understood as more or less lasting forms of organizing (Sillince, 2009). Instead of looking for exogenous reasons for their endurance, we ask how space provides endurance to the practices surrounding creative hubs, eventually leading to organizing. 
We look for answers by examining ethnographic data the first author gathered at two newly established creative hubs in Amsterdam. Our findings suggest that it is the spatial dimension of creative hubs that allows them to make organizing practices endure. More specifically, it is the assemblage of artefacts that substantiates space that makes endurance possible. Workers from Relaunch, our first space, needed to move when the managing company of the warehouse they resided at, declared bankruptcy. In the second case, ABS had been recently established as a creative hub, and its managing organization sought to instil a community feeling to bring together its diverse tenants. In both cases, our analysis reveals, the creative hubs faced their challenges drawing from the joint material and semiotic facets of space, in alignment with Kuhn and Burk's (2014: 149) suggestion that "the relevance of physical space (i.e. sites) in organizing is always already connected with symbolic activity". Indeed, as our findings show, space provides durability to organizing and, as such, contributes to the constitution of organizations. While ample literature discussed the relational and practical assemblage of space (Thrift, 1999; Massey, 2003), our data illustrates that space, once it is assembled, also becomes active in organizing and makes emergent organizations endure beyond the attributes of any of their components (Taylor \& Van Every, 2000). After we review the literature that discusses how organizations endure, we will proceed to suggest the role space may play in this process.

\section{How does space contribute to the emergence and endurance of organizational practices?}

The literature typically assumes that organizations are mostly stable. The way organizations may succeed at changing or at resisting unwanted change has dominated organizational studies (e.g. Suddaby and Foster, 2017; Stouten, Rousseau and De Cremer, 2018). 
Alternatively, some research views organizations as continuously changing (e.g., Tsoukas and Chia, 2002), and seeks to identify how, in this turmoil, they may act and to endure in time (Farjoun, 2010). For instance, for structuration theory, stability proceeds from the interplay between structure and the individual actions where it is expressed and reproduced (Barley and Tolbert, 1997; McPhee, 2004). The "duality of structure" (Giddens, 1984; McPhee and Zaug, 2000) materializes as the "institutional work" that simultaneously changes and reinforces institutions (see Zundel et al., 2013).

Another perspective puts the emphasis on communicative practices such as conversations, and on their inscription into texts such as documents and technology. Procedures, standards, values and other organizational figures are conversationally established and (re)negotiated, and can last by being inscribed in texts (Taylor and Van Every, 2000). In each situation, new conversations invoke those texts, thus making them relevant again and initiating a new iterative cycle (Cooren et al., 2007; Cooren, 2010). A text can gain more authority, and such authoritative texts may allow or constrain the renegotiation of other figures (Kuhn, 2008). This approach, the Communicative Constitution of Organizations (CCO) (see Schoeneborn et al, 2014), comprises several perspectives (Putnam \& Fairhurst, 2015), including the Montreal School (also known as TMS). Indebted to actor-network theory, TMS suggests that the endurance of organizations can be attributed to documents, objects and technologies (Cooren, 2004; Ashcraft et al., 2009; Cooren and Bencherki, 2010; Cooren, 2015). TMS, however, does not consider how spaces - in the ordinary sense: offices, corridors, etc. - play a part in organizing. By recognizing that space is an assemblage of artefacts and practices, we thus extend CCO by taking seriously its underpinning relational ontology (Kuhn, Ashcraft, Cooren, 2017). 
The view of space we put forwards departs from usual definitions. Taylor and Spicer (2007), for example, identify three definitional axes: (1) space as distance and proximity (e.g., Hatch, 1978; Fayard and Weeks, 2007); (2) space as a materialization of power relations (e.g., Wasserman and Frenkel, 2015; Courpasson, Dany and Delbridge, 2016); and (3) space as lived experience (e.g., Yanow, 1998; De Vaunjany and Vaast, 2014). Organization studies currently emphasize either practice's effects on space, or the other way around. Some studies, for instance, show how space facilitates or constraints cooperation, innovation, or community (Haner, 2005; Garrett et al, 2017), therefore attributing agency to space (Yaneva, 2009). Others consider space as the result of relational practice (see Massey, 2003; Lefebvre, 1991) and look at how performances (re)create transient spaces (Tyler and Cohen, 2010; Michels, 2012).

In contrast, we suggest not differentiating space from the practices through which it is substantiated and materialized (Cooren, 2010). To avoid this distinction, we recognize practices and relations are both material, because to exist they must take flesh in a body, be inscribed in a document or in technology, or be spoken through the sound of one's voice. There are not, on the one hand, human relations, and on the other material assemblages that constitute space: both exist on the same plane. If there is a difference, it lies in the greater or weaker robustness of some relational assemblages (Latour, 1986b; Martine and Cooren, 2016). We could say, in brief, and to reformulate Latour's (1986a) title, that space is relations and practices made durable.

In this sense, space is not a container of practice. We suggest, instead, that space and practice reflexively account for each other (Macbeth, 2001; Zemel and Koschmann, 2016). For instance, a café is not only a collection of tables and chairs along with a counter; coffee-drinking practices provide meaning to these artefacts. Similarly, while a line of idle people waiting in a café would be perplexing, it would make sense under a sign indicating a number and make it 
recognizable as a bus stop. Space intertwines artefacts and practices in a homogeneous whole, the difference being that coffee machines and signs are longer-lasting than gestures, and may serve again and again as resources for people to agree on where to get coffee or to queue.

\section{Methods and empirical setting}

Organizational practice is regularly studied using ethnography, to "represent $[\mathrm{t}]$ the social reality of others through the analysis of one's own experience" (Van Maanen, 1988: xiii). That is why ethnography has been employed to examine activities as they unfold, including routines (Feldman and Orlikowski, 2011), collective document use (Vásquez et al., 2017), the way situated knowing scales up to the collective level (Nicolini, 2011) and the negotiation between practice and technology (Leonardi, 2011). Ethnography, indeed, allows "zooming in and zooming out" and relating local practice to the broader organizational picture (Nicolini, 2009).

In parallel, studies have used ethnography to take a close look at materiality and space. Ethnographic analysis has revealed the connection between space and community-building (Yanow, 1995; Garrett et al., 2017) or organizational legitimacy (De Vaujany and Vaast, 2014), as well as people's varying interpretations of space (Riach and Wilson, 2014). Given that ethnography can study both practice and space independently, we suggest it is a method of choice to tease out their relation.

Choosing ethnography also appears sensible given that literature in the CCO tradition uses ethnographic methods to document artefacts' contribution to organizational endurance and to observe the concrete difference artefact make in organizing, including documents, instruments and computer files (e.g., Cooren, 2004; Schoeneborn, 2013; Bencherki, 2016). Contrary to other methods, ethnography requires researchers to welcome surprise and to make familiar contexts 
strange again (Ybema and Kamsteeg, 2009). When such an attitude is adopted, then artefacts' contribution to sociality becomes evident. Since space is an assemblage of artefacts, ethnography should likewise highlight these assemblages' participation in collective action.

The first author conducted ethnographic research at two creative hubs in Amsterdam, whose city government supports the transformation of neglected property (Peck, 2012) to accommodate freelancers, mostly from the creative and cultural sectors (O'Connor, 2010). When the first authors became aware, in the spring of 2013, that two such hubs were to open - each in a different location, targeting different clienteles and adopting its own managements format ${ }^{1}-$ she saw an opportunity to study how joining such places allows workers to expand their network and initiate collaborations. She was able to secure access to both hubs after a few pilot visits, the agreement being that she would spend two months, starting in the autumn of 2013, as a full-time researcher at each creative hub. A handful of follow-up visits were also planned, which continued up to July 2014. Throughout the research, the first author took part to each site's activities and even became one of ABS's tenants (see Cnossen, 2018).

Each site involved a range of data-gathering strategies. The researcher jolted field notes after informal discussions and to keep track of her experience as she engaged in odd jobs, as when she delivered mail to tenants. She committed in writing both facts and her impressions, including physical sensations, thoughts and questions that emerged from her interactions (Emerson, Fretz, and Shaw, 2011; Chiseri-Strater and Sunstein, 1997). She also distributed questions to tenants regarding their occupation, educational background and the reasons why they joined either Relaunch or ABS. In addition, 26 open-ended interviews, lasting from 45 minutes to two hours, were recorded and transcribed, as were conversations with each space's manager and with city official, which offered some context information. 
Using an inductive approach and going back and forth between the data and the literature, both authors searched for relevant "breakdowns" that challenged our interpretation of what was going on (Alvesson and Kärreman, 2011). In Relaunch' case, an important breakdown had to do with the artists' desire to remain together even though it would be easier to part ways following the property owner's bankruptcy. As for ABS tenants, they were initially a haphazard collection of people, but eventually all identified powerfully the drawing of a chicken, which became their rallying cry and an intriguing puzzle for us. The researcher's long-term implication with ABS made this second case an instance of "observant participation" (Moeran, 2009) or "at-home ethnography" (Alvesson, 2009; Cnossen, 2018). As for the second author, he was an outsider to both sites, which led to "collaborative auto-ethnography" (Chang et al., 2013). Our cooperation helped the first author reflect on how she moved across "work-worlds" (Gilmore and Kenny, 2015). Together, we wrote up vignettes with a "variety of shapes, substances, transmutations, multi-dimensionalities, and angles of approach" (Richardson, 2000).

The vignettes emphasize different facets of the challenge of organizational continuity, but also leave out several events that took place but were of less significance for the project, while preserving the narrative thread (Sturdy et al., 2009: 66). Using open coding, we condensed and categorized the vignettes until we could identify the participants' most relevant practices (Kvale, 2006). Practices are recurring and purposeful (Nicolini, 2012), and constitute social phenomena, including organizations (Schatzki, 2005). We particularly focused on the practices through which space, as an assemblage, could contribute endurance to Relaunch and ABS, throughout the unstable times they traversed. We present the outcome of our analysis in the discussion section. 


\section{Relaunch: Preserving the collective thanks to the spatial assemblage of containers}

It is a cold autumn morning when the researcher enters a warehouse on an industrial street in one of Amsterdam's fringes. The welcome committee consists on an ensemble of large things: a metal sculpture, minivans turned into makeshift food trucks and woodworking apparatus, to name a few. Hardly lit and high-ceiled, the space was punctuated with evenly spread-out shipping containers, their regularity only interrupted by noisy machines and people carrying odd objects. From one of the food trucks came out an older gentleman. Like a farmers' market, each artist had their own spot, and yet a sense of community emanated from the collective.

The manager welcomed the researcher and walked her around the space. At one point, he showed her a trailer in the middle of the space: "There will be coffee here." When they walked in and were enveloped with the dry warmth of electrical heating, the researcher realized how cold the warehouse was. A speaker blew out the deep voice of Tom Waits. When she sat down at a table, close to a window, looking at people walk in and out greeting each other, the researcher thought the café trailer felt like a cosy blanket. Although it was nearly noon, some people were clearly seeing each other for the first time on that day.

After they left the café trailer, the manager took the researcher on a tour of the various artists' spots. Each person, she learned, was attributed one shipping container and an equivalent lot next to it, the open concrete space a negative of the box next to it. They could use, for instance, the container as an office, and the lot as an atelier for mending, welding and scraping. For instance, Jesse, an artist working on large installations, used his container as storage space, and actually worked on the adjacent lot. The artists showed the researcher into their containers, which resembled an office, store room or a cabinet of curiosities, depending on each person's 
profession. While the containers were large, their finite size still meant that choices had to be made concerning what could be kept, and negotiations took place among tenants to trade available space. Otis, a furniture designer, captured the researcher's overall feeling: "With all those containers lined up, it conveys a certain rough-looking image" (Interviewee 1).

Six months after this first visit, the community found itself in a legal conflict with the property owner, who went bankrupt. Eventually, some tenants started moving elsewhere. The management had already spent people's deposits, which meant for some tenants that they had no cash to move although they had to. Through the weeks, the researcher witnessed the international, English-speaking collective turn into a small group of Dutch people, the only remaining expat having lived in Amsterdam for decades.

Among this smaller group, the project of sticking together emerged during the weekly meetings they started to hold on Mondays. These meetings were prefaced by participants scavenging for cups and glasses in each other's containers, to make sure everyone could be served drinks. The hunt was also an opportunity to gather the electric cords necessary to brighten the late-evening meeting. This habit, the researcher felt, made everyone a part of the collective effort of having these meetings, however modest their contribution was.

A filmmaker turned community organizer and Otis, a banker turned furniture designer, joined forces to sketch out a plan for "Relaunch", a new creative hub that would house the remaining artists. While they were unabashed by the paperwork, they did feel resistance from the others, especially concerning the money and time it would take to move: "I have literally zero euro in my bank account", said a young artist; "I have good assignments coming my way and I must have a studio up and running next month", someone else said. "Someone in the group had been using his deposit for maybe 15 years already, moving from place to place with that money", 
Otis explained during an interview (Interviewee 1). The date on which they would be evicted was approaching, but by then the two leaders had been able to obtain a subsidy from the Amsterdam city council, and secured an empty warehouse on the same street.

The move could finally take place when the deposit situation was resolved: as a compensation for the bankruptcy, the containers and the café trailer would be given to the tenants along with the rest of the inventory. What was a "context" for their activity thus became the artists' property and would be moving with them: the spatial assemblage that shaped their organization could now be reproduced in the new location. The new warehouse was down the street, of a similar size, and the containers would permit the nearly-exact reproduction of the artists' lots. Tenants started to discuss who would be their neighbour, or whether they would be closer to the centre or to the entrance, as it became clear the new space would be similar to the old. Moving the containers meant the storage options would be similar, including existing arrangements to store stuff in a neighbour's container. A central area could be reproduced to allow for meetings, and the tenants even inherited the foldable chairs and the benches they used to that purpose. Said otherwise, the ability to move the same artefacts meant they could be assembled in similar configurations, thus making it possible to reproduce the relational constitution of their collective.

Insert Figure 1 here

The spatial assemblage of artefacts - specifically, how containers were spread throughout the warehouse - contributed to providing endurance to relations between artists. What is more, though, is that they also strengthened them. During one of the lasts weekly meetings before the 
move, it became obvious that not all the artists understood the imminence of what was coming, especially since many people had been away. One person urged: "Everyone has to mark their stuff tonight". Directives were laid out and, during that very evening, everything was packed up in the container, which went back from ateliers and museum to their "original" usage, namely storage units. A series of labelled containers, dispersed in the large factory, now stood for the community's organizing principle. To the artists, this meant that, after months of conversations, they would finally be able to move while remaining together. But the move would not only reproduce their collective, it would also strengthen it. In a sense, the two became hard to distinguish: the relations between Relaunch members also consisted in their joint work to reproduce and preserve their common space.

When they moved, the artists kept the tradition of holding weekly meetings. When the researcher attended one of them, a few months after the move, she was struck by the similar spatial set-up, with the shipping containers distributed throughout the new factory, and with lots next to each one (see Figure 1). People were tending to the rectangle next to their container, painting the floor and laying concrete where necessary, as if it were a garden. Just like before, when the meeting was called, people spilled out from their containers, and walked to the "neutral ground" in-between containers, scavenging for cups, glasses and electric cords on their way.

\section{ABS: Giving meaning to the building through a chicken's image}

An improbable candidate for a creative hub, the ABS building - a brown, grey and dark green dental hospital built in the 1960s - opened its doors at the beginning of 2012 in two phases. Its old administrative section was available first and it is only eighteen months later that the other portion of the building, which was contaminated with asbestos, became habitable. This 
resulted in a palpable challenge to integrate two tenants' populations into a harmonious whole. To this day, tenants continue to identify themselves as "phase 1" or "phase 2". In addition to the physical aspects of the building, the issue came from the fact that Urban Hubs, the managing organization, adopted more lenient criteria to select phase 2 tenants. As a multimedia artist explained: "From those who were initially selected, more and more said no because they had already found another studio [by the time phrase 2 became available]. This triggered a strange sort of compensation [and] suddenly we were facing the fact that Urban Hubs had trouble finding people" (Interviewee 2). The resulting community spurred from the building as a material assemblage.

Only a few months after tenants began moving in, a huge chicken popped up at the top of the ABS building. The bright blue chicken indicated that something was going on in the apparently innocuous building and was a welcome trace of colour in that dull part of town. The hand-drawn outline and the absence of any accompanying text made it clear it was not a company logo, and yet its clear shape suggested it was not an art work.

Insert Figure 2 here

About when the chicken first appeared in the spring of 2013, the first author became herself a tenant at ABS. In addition to living space, she had a small office where she could write and study, right between a Greek snare instrument creator, a laser artist from Russia, a jeweller and two deejays. Since many people had just moved in, things were still looking for their place: 
people carried around piece of wood, fabric and buckets of paint; musicians soundproofed their studios with varying degrees of professionalism; tools were borrowed, phone chargers were a rare resource, and everyone contributed odd cups and dishes and a motley of cutlery to the common pantries. In the jolly turmoil, the chicken found its way and now had little siblings spray-painted in the corridors, above a bookshelf or at the bottom of a doorpost (see Figure 2), at the rate of one a week or so. Some of them were crossbred with a dinosaur or a rabbit.

When the first author was still unpacking her boxes, Ronald, the technical manager, came to greet her. He explained the chicken was his project: "It's a bit of a joke obviously, I just wanted to do it. From when we started the place, it was just us," referring to Lisa, the rental and community manager, and himself. Ronald had studied graphic design, but he was now trusted with all technical problems at ABS, and he was not intimidated by any construction work. While both Lisa and he were Urban Hubs employees, they were in fact free agents: "They [Urban Hubs] do not come around a lot. So, I just wanted to do something that was really about this place and the people who make it", Ronald explained of the chicken. "It is becoming a little bit like an unofficial logo."

On June 13, 2013, ABS officially opened it door and a party was organized, bringing in local residents and art lovers. For months, a tenants' committee, along with Lisa and Ronald, had been preparing the event. One committee member, a recently graduated art student, was already strongly attached to the building and took his involvement in the project as an honour: "A lot of other people could have taken on the task of organizing this festival too, but still, they [Urban Hubs] saw this is me" (Interviewee 4). The event included performances by musicians from the building and showcased the work of artists. Another tenant, fascinated by the chicken's new status as the building's anti-logo, joined forces with Ronald to make t-shirts with various 
versions of the animal's image, which she sold during the festival with quite some success. The chicken had already moved past being an individual project and had become a symbol for the building. Reflecting on the building, one artist who was among the first phase tenants, said: "I had the need to become part of something larger. I was hoping for a community. It is only the beginning, but already with a few people [...], a community is emerging” (Interviewee 2).

The chicken was now on walls and doors, but also on people as they walked through the building's corridors, but its reproduction continued to rely on its original designer. Things changed when Ronald fell ill at the end of the summer of 2013 and was out for a year on sick leave. It is during that time that the first author conducted her fieldwork as such (besides being a resident). She could witness the proliferation of the chicken and the tenants' enthusiastic response to it.

First, Lisa commissioned a website from a design studio housed in the building. The website would list tenant profiles and offer general information about ABS. ${ }^{2}$ During a monthly meeting of tenants, the designer solicited everyone's opinion on three possible mock-ups, which all prominently featured the chicken, even though this was not required or even suggested. The chicken truly proved itself, though, when "phase 2" was complete, in January 2014. Suddenly, the number of tenants doubled, which threatened the familiarity that the original tenants shared. Some people put the blame on Urban Hubs's management: "I think that, in reality, there is not so much communication going on between the people who are using this place. They come down there, but they don't really talk to each other that much, there are not many opportunities to really gather round except for the meeting once a month, at which a small percentage of people usually show up.” (Interviewee 3). 
The ABS assemblage initially stuck together through one-on-one communication and physical proximity. However, with the influx of new tenants, impromptu conversations in the hallways became more difficult, especially since, right after the main entrance, tenants of each "phase" parted ways in opposite directions, making chance meetings unlikely.

To deal with sudden increase in size, a "borrol" was held each month, the word being a pun on the Dutch word for a drink (borrel), and the verb to roll ( $r o l)$. A group of people stacked a shopping trolley with beer and other beverages and pushed it down the corridors, inviting others to join on the way. The troupe would stop for a peek at each studio and artists would tell them a few words about their work. The borrol allowed tenants to discover new parts of their building and to spot the chicken throughout. The chicken acted as a catalyst in the continuous tightening and strengthening of the building's assemblage as it had an anchoring effect. Despite the building's impressive size and diversity, the researcher noted as she took part to borrols, that the chicken gave a sense of continuity through the collective exploration. It did not create that sense of sameness alone: it did so thanks to the combined effort of humans to (re)invent the chicken, on studio doors that would be opened to welcome the group, on the rolling wheels of the shopping trolley, and - importantly - on the steady flow of beer.

The growth of ABS's population meant it became more difficult to keep things under control. People began abandoning leftovers from their projects in the corridors and others stole plants. Notes were posted urging neighbours to clean up or to return missing things. However, being part of such a large building with lots of freedom also meant that many interesting initiatives would emerge: temporary installations, a book swap corner, or video projects allowing tenants to display their work. These projects, but also the leftovers and the angry notes, all reminded tenants that the building was a spatially organized living collective. Some of the 
cleaning tasks were attributed to a fashion designer in exchange of a small salary, but residents remained collectively responsible for common areas and not everyone had the same standards of cleanliness. In the absence of a clear rule, tenants were reminded of their duties - but also of their membership in the collective - by the building's ongoing state of buzzing messiness.

The growing assemblage maintained the chicken at its centre. A collective of fashion designers, The Fashion Chickies, joined the building and adopted the chicken on their studio door, their flyers and social media presence. The collective did so without knowing that the chicken had begun as a personal project. Without being the only element, the chicken was an important component that connected people throughout the building and gave coherence to their organizing efforts.

In this sense, the chicken partly made up for the ABS building's lack of internal integration. It was adopted and reproduced across a range of activities and as tenants explored their building and maintained their collective. Pushing a trolley with alcohol to meet neighbours or drawing their attention to areas needing repair, they responded to the building's demands while making it meaningful to them. These efforts were so successful that the chicken expanded to new territories: after t-shirts, company names and websites, it now conquered the building next door. When students from a residential hall started their monthly newsletter, they adopted the chicken as their logo, to the great joy of ABS tenants. To a visual artist, this was "very endearing", and the consultant who made the t-shirts said that Ronald, who was still on leave then, "had always suspected the chicken was here to stay". 


\section{Analysis: How space and practice reflexively account for each other}

The two cases reveal that people's practices that did not just take place within space, nor 'just' constituted space (Thrift, 1999; Massey, 2003), but that they implicated space into constitutive and organizing processes. Space, in this sense, was not neither only constraint to activity, nor only outcome of activity. Our data shows that people entertained intricate relations with space, as they pursued work-related or creative goals. Practice engaged with the material assemblage of space when people used a trailer as a café and exchanged storage space, when they disseminated the image of a chicken to provide meaning to their building and explored its winding hallways with a beer-packed trolley, or when they drew each other's attention to areas that needed maintenance. It is insufficient to describe these practices as only constrained by space, or as only constitutive of it. Instead, careful attention to how practice and space relate shows that they also reflexively account for each other (see Table 1).

Insert Table 1 here

\section{How space shapes practice}

In both vignettes, several cases illustrate how material assemblages shaped organizing practices. In the Relaunch case, for example, the café trailer was positioned at the centre (relative to the other containers) and was heated, thus constituting a meeting place for all artists. The massive warehouse allowed leaving space between containers, which became lots people used as an extra work space. Containers became workshops, exhibition rooms or offices where artists invited each other. Yet, some projects required addition room, which meant that some people 
would negotiate with neighbours to store their material in their container. The layout of the containers also created a "neutral zone" away from any one artist's lot, making it a choice location for meetings. The material assemblage of containers and trailers therefore made way for organizing practices and allowed them to endure.

In the case of ABS, the renovation work made necessary by asbestos segregated tenants into two groups, both temporally and spatially. The state of the building demanded all tenants to collaborate to maintain it, and its winding hallways became opportunities for collective, beerfuelled exploration in search for continuity, which was offered by the chicken's many incarnations. The building's material assemblage, in this sense, underpinned organizing practices.

\section{How practice shapes space}

People's practices also shape space and provide it with meaning. At Relaunch, the fact that people went to the central trailer to grab coffee, played music there, and that it was the only heated trailer, constituted that place as a café. It became more than just a trailer that happened to be in the centre: it became a meeting place. Also, visiting each other's containers began as a curiosity, and turned into a ritual that confirmed the containers as people's "home" within the warehouse. Scavenging for cups was a recurrent practice that concretely assembled a makeshift meeting room, but also became another opportunity to explore each other's containers while searching for cups. Finally, when trading extra space, artists embedded bits of each other's project into their own workspace, thus tangibly asserting that they were part of a collective.

At ABS, tenants would share leftover material and equipment, moving them around the building and, sometimes, abandoning them in a hallway. The lingering material gave cues as to 
what neighbours were working on and gave the building a sense of buzzing creative activity. Cleaning up together was also a chance to get to know others and share ideas for enhancements, such as displaying video art. For their part, the borrol and the chicken's multiple incarnations were an invitation to connect the building's various areas, by strolling around and discovering what was being done, and offering coherence to the otherwise desultory building. The t-shirts, The Fashion Chickies and the student magazine were all practices that infused meaning and a sense of shared belonging to the building's assemblage.

\section{Organizing as the reflexive accounting of space and practice}

The wheel of the two hubs kept turning thanks to the reflexive relation between space (as material assemblage), which constrained or afforded practices, and practices that provided meaning to space. At Relaunch, the café trailer was at once made possible by its central position and made meaningful as a café by the practices that took place there: making coffee, playing music, meeting with others, and so forth. The lots artists used as extra workspace also illustrate the same reflexive relationship: their existence as lots relied both on the unoccupied space available between containers, and on the nature of the work conducted there. Similarly, the weekly meeting unfolded in an analogous way each time, because it took place at the same spot and therefore perpetuated the cup-scavenging and electric cord-hunting rituals - but also because these rituals contributed to turning that location into the meeting spot. A turning point for Relaunch members took pace during one of those meetings, when the artists decided to finish packing their containers and mark them to bring them along. In that sense, the meeting illustrated the breadth of relations between practice and space: as an organizing practice, it took place 
within a spatial assemblage, supposed interaction with the assemblage, but also consisted in conversations about reassembling it in another location.

At ABS, the building's posed significant constraints on tenants' ability to socialize. These constraints made the borrol and the chicken essential and were also made relevant by these two recurring practices. Indeed, the building would not have posed such challenges to socialization if tenants had been content to remain in their own studios, like in many offices. The borrol, in that sense, both served to break from isolation and get to know the building, and turned the building's nooks and crannies into a fun opportunity to explore together. In a different space, the borrol would not have had the same meaning, while the ABS building would also resonate differently without the borrol. In the same way, the chicken popping up at the top of the building and in its many intricate corners made it more than a logo: each of its appearances was a breadcrumb marking a trail through the maze. The chicken meant something different in this building than it would have elsewhere, and people's engagement with it, for instance by replicating and crossbreeding it, contributed to making it a festive appropriation of the building. The chicken, then, also gave meaning to the space: the hallways became place to discover what neighbours had done with the chicken and how they creatively subverted the building's daunting appearance. The collective appropriation of the building also materialized in the project scraps people left in the corridors and shared with each other, which were a testimony of tenants' hard work and buzzing creativity. The small studios made these practices necessary by preventing people from storing extra material. The age of the building also meant there were plenty of opportunity for maintenance and jointly cleaning up and repairing it was also a chance to consider how it could be improved, for example with a book swap corner. 
Both cases show that accounting for the endurance of practices cannot be done only by looking a single artefact. Space is an assemblage of artefacts: the layout of the containers in the warehouse, their size that could accommodate a workshop or an office, and the room available between them for a lot, all made a difference at Relaunch. At ABS, the building's age, asbestos contamination, its tortuous hallways and the fact that it splits in two after the main entrance, all contributed to making it what it became. Yet, the assemblages' physical aspect is but half the story. The practices that take place in there provides them with meaning and makes them what they are, like a café. That is why we suggest that practice and space reflexively account for each other.

\section{Discussion and Conclusion}

Thinking of space and practice as reflexively accounting for each other draws attention to four connected issues in current theorizing about space in organization studies and related fields. It helps explain the apparent tension between, on one hand, studies stressing the importance for organizing and work and, on the other hand, studies insisting that work practices cross spatial boundaries. It allows comprehending materiality in organizing not only in terms of individual artefacts (a document, a piece of software, etc.) but also as a relation between artefacts and practice that form assemblages. It also warns against over-emphasizing discourse as a lens to explain the part materiality and space play in organizing. Finally, it reveals that space may contribute to organizationality (Dobusch and Schoeneborn, 2015), even where there are no organizations as such.

Thinking of space and practice as reflexively accounting for each other, as the cases of Relaunch and ABS have shown, offers some unity to diverging trends of theorizing space. These 
have either insisted that space is highly consequential for collaboration (Garrett et al, 2017), political mobilization (Valli, 2015), and interaction (Fayard and Weeks, 2007), or that practices transcend space because of new mobilities (Costas, 2013; Kociatkiewicz and Kostera, 2015). It turns out practice actively engages with space: the space where it takes place defines it as much as it defines space, both of within organizations and outside. The reflexive relationship allowed Relaunch workers' practices to transcend space (when they had to move) not despite the physicality of space, but because of it - because they could reassemble it elsewhere. Similarly, ABS's building made socializing difficult, but in the end, it is because its corridors offered chances for exploration and because people came together to maintain it, and because its many recesses were so many occasions for the chicken to pop up, that people could socialize. Organizationality emerges in the iterative aspect of this reflexive process, as space provides endurance to practice, which simultaneously constitutes space as meaningful. In other words, if space can be actively tinkered with, the interplay that emerges between material assemblages and organizing practices can provide fruitful soil for some form of organizationality. If possible, creative hubs should allow users to work with the space, not because it guarantees a sense of collectivity, but because in the absence of so many other forms of stability, independent creative workers can at least reap the benefits of a collectively assembled social fabric. Whether this can make up for other forms of precarity among this population remains an empirical question for further investigation.

While previous work has suggested that the endurance of practice stems from its inscription into artefacts (Cooren, 2004; Cooren and Bencherki, 2010), the cases of Relaunch and ABS show that practice also endures thanks to its iterative engagement with assemblages of artefacts that make-up space. Indeed, regularly meeting at the same spot - comprising the 
assemblage of foraged cups and improvised lighting - turns it into the meeting place; having coffee in the same trailer, with heaters and music and the smell of freshly brewed coffee, turns it into a café, and toiling on the area that's delineated by the trailers makes it a lot. In this sense, we nuance the literature's tendency to over-emphasize the physical nature of a single artefact, as the durability of practice cannot always be reduced to the agency of a single tool, document, or machine. Thinking in terms of assemblage provides a more comprehensive account of the activities that take place in relation to it. Speaking in terms of space allows both considering the individual artefacts that compose it and recognizing that the meaning of practice cannot be reduced to any single one of them, but rather proceeds from their relational weaving.

Conversely, research on space should also avoid over-emphasizing sensemaking and discourse, which have been dominant foci in the study of organizing. Attempts at connecting discourse to materiality have at times turned out to favour the discursive side of the equation (Putnam, 2015). Space has been described as “stories so far" (Massey, 2003) or as woven together through communication (Vásquez and Cooren, 2013). Shared understanding matters in how people experience space and jointly make sense of it, yet the very tangible character of the practices illustrated in the cases - exploring the hallways, cleaning and fixing the building, spray-painting chickens, etc. - shows that engagement with space cannot be reduced to talking about it or understanding it in one way or another. Engaging with space is a (socio-)material process of assembling, similarly to Latour's (2005) use of the word. Sensemaking is but one set of practices that may take place in relation to space. Insisting on interpretation may recreate a distinction between a physical space that would be "out there", waiting to be made sense of by human beings. It may also reiterate a theory of action as intentional and consecutive to cognitive decision. Instead, by considering space as assembling a variety of practices along with physical 
artefacts, we can reconcile old dualities between the social and the technical, discourse and materiality, action and intention, and so forth.

In that sense, considering space and practice as reflexively accounting for each other both aligns with and extends research on the part discourse plays in the constitution of organizations. While studies recognize that materiality participates in constitutive processes (Cooren and Bencherki, 2010; Cooren and Matte, 2010), they still mostly focus on artefacts that are "communicational" in nature, in the sense that they inscribe linguistic signs or marks (such as documents or computer files). Alternatively, they focus on the interactions through which participants use, interpret or design those artefacts. This emphasis on communicative artefacts and their interpretation may result from this tradition's analytical grounding in conversation analysis or discourse analysis, which may turn the researcher's attention to language at the expense of other practices (Bencherki, 2016; Wilhoit, 2016). Our two cases offer empirical illustrations of organizational practices besides conversation and verbal language use, including concrete engagement with materiality and space, thus responding to Kuhn and Burk's (2014) call to study space's physical dimension.

Our two creative hubs reveal that their spatial dimension contributed to enabling and perpetuating organizing practices even though they were not organizations as such. Sharing, exploration, maintenance work, and moving all require coordination, planning and other “organizational” practices to be performed. People congregated (to talk about their space) in recognizably analogous ways from one week to the next, they worked on their lots, maintained their building together, and organized events to foster socialization. They created a "brand" for their building and made sure they could recreate their collective elsewhere in a practically identical spatial arrangement. Space, in participating in making those different organizational 
practices similar from one moment to the next, is not only a container where organizing happens, or an outcome of practice, but also as a key ingredient of organizational constitution, existence and action. In this sense, it contributes organizationality (Dobusch and Schoeneborn, 2015) even to collectives that do not think of themselves as organizations.

\section{Funding}

This research was supported by funding from The Netherlands Organisation for Scientific Research (grant number 407-12-008) and the University of Amsterdam.

\section{Notes}

1 The researcher also observed a third space, which was eventually excluded because it did not face similar challenges, as it mainly rented space to small organizations. 


\section{References}

Alvesson M (2009) At-home ethnography: Struggling with closeness and closure. In: Ybema S, Yanow D, Wels H, Kamsteeg F (eds.), Organizational Ethnography: Studying the Complexity of Everyday Life. Newcastle: Sage.

Alvesson M and Kärreman (2011). Qualitative Research and Theory Development: Mystery as Method. London: Sage.

Anteby M (2010) Markets, Morals, and Practices of Trade: Jurisdictional Disputes in the U.S. Commerce in Cadavers. Administrative Science Quarterly 55(4): 606-638.

Ashcraft KL, Kuhn TR and Cooren F (2009) Constitutional amendments: "Materializing" organizational communication. The Academy of Management Annals 3(1): 1-64.

Barley SR and Tolbert PS (1997) Institutionalization and structuration: Studying the links between action and institution. Organization Studies 18(1): 93.

Bencherki N (2016) How things make things do things with words, or how to pay attention to what things have to say. Communication Research and Practice 0(0): 1-18.

Bloss R (2011) Mobile hospital robots cure numerous logistic needs. Industrial Robot: the international journal of robotics research and application 38(6): 567-571.

Brown B and O'Hara K (2003) Place as a Practical Concern of Mobile Workers. Environment and Planning A 35(9): 1565-1587.

Brummans BHJM (2007) Death by document: Tracing the agency of a text. Qualitative Inquiry 13(5): 711-727. 
Bruneel J, Ratinho T, Clarysse B, et al. (2012) The evolution of business incubators: Comparing demand and supply of business incubation services across different incubator generations. Technovation 32(2): 110-121.

Capdevila I (2015) Co-working spaces and the localised dynamics of innovation in Barcelona. International Journal of Innovation Management 19(3): 1540004.

Cappelli P and Keller JR (2013) Classifying work in the new economy. Academy of Management Review 38(4): 575-596.

Chang H, Ngunjiri FW and Hernandez K-AC (2013) Collaborative autoethnography. Walnut Creek, NY: Left Coast Press.

Chiseri-Strater E and Sunstein BS (1997) FieldWorking: reading and writing research. Upper Saddle River, N.J: Prentice Hall.

Cnossen B (2018) Whose home is it anyway? Performing multiple selves while doing organizational ethnography. Journal of Organizational Ethnography, in press.

Cohen RL (2010) Rethinking 'mobile work': boundaries of space, time and social relation in the working lives of mobile hairstylists. Work, employment and society 24(1): 65-84.

Cooren F (2004) Textual agency: How texts do things in organizational settings. Organization 11(3): 373-393.

Cooren F (2010) Action and Agency in Dialogue: Passion, Ventriloquism and Incarnation. Amsterdam/Philadelphia: John Benjamins.

Cooren F (2015) In medias res: Communication, existence, and materiality. Communication Research and Practice: 1-15.

Cooren F and Bencherki N (2010) How things do things with words: Ventriloquism, passion and technology. Encyclopaideia, Journal of Phenomenology and Education (28): 35-61. 
Cooren F and Matte F (2010) For a constitutive pragmatics: Obama, Médecins Sans Frontières and the measuring stick. Pragmatics and Society 1(1): 9-31.

Cooren F, Matte F, Taylor JR, et al. (2007) A humanitarian organization in action: organizational discourse as an immutable mobile. Discourse \& Communication 1(2): 153-190.

Corman MK (2017) Paramedics On and Off the Streets: Emergency Medical Services in the Age of Technological Governance. Toronto: University of Toronto Press.

Costas J (2013) Problematizing mobility: A metaphor of stickiness, non-places and the kinetic elite. Organization Studies 34(10): 1467-1485.

Courpasson, D., Dany, F., \& Delbridge, R. (2017). Politics of place: The meaningfulness of resisting places. Human Relations, 70(2), 237-259.

Czarniawska, B (2005) Karl Weick: Concepts, style, and reflection. Sociological Review, 53(1), 267-278.

Czarniawska, B. (2013) Organizations as obstacles for organizing. In: Robichaud, D. \& Cooren, F. (eds.), Organization and Organizing: Materiality, Agency, and Discourse. New York: Routledge.

Dean K and Massumi B (1992) First \& last emperors : the absolute state and the body of the despot. Brooklyn, N.Y.: Autonomedia.

De Vaujany F-X and Vaast E (2014) If these walls could talk: The mutual construction of organizational space and legitimacy. Organization Science 25(3): 713-731.

Dobusch L and Schoeneborn D (2015) Fluidity, Identity, and Organizationality: The Communicative Constitution of Anonymous. Journal of Management Studies: 1005-1035. Duff C and Sumartojo S (2017) Creative Assemblages: Material Practices in the Creative Economy. Organization 24(3): 418-432. 
Emerson RM, Fretz RI and Shaw LL (2011) Writing Ethnographic Fieldnotes. 2nd ed. Chicago guides to writing, editing, and publishing, Chicago: The University of Chicago Press.

Evans G (2009) Creative cities, creative spaces and urban policy. Urban Studies 46(5-6): 10031040.

Farjoun M (2010) Beyond dualism: Stability and change as a duality. Academy of Management Review 35(2): 202-225.

Fayard A and Weeks J (2007) Photocopiers and water-coolers: the affordances of informal social interaction. Organization Studies 28(5), 605-634.

Feldman MS and Orlikowski WJ (2011) Theorizing Practice and Practicing Theory. Organization Science 22(5): 1240-1253.

Gandini A (2015) The rise of coworking spaces: A literature review. Ephemera 15(1): 193.

Garrett L E, Spreitzer G M and Bacevice P A (2017) Co-constructing a sense of community: the emergence of community in coworking spaces. Organization Studies, forthcoming.

Giddens A (1984) The constitution of society: outline of the theory of structuration. Cambridge: Polity Press.

Gilmore S and Kenny K (2015) Work-worlds colliding: Self-reflexivity, power and emotion in organizational ethnography. Human Relations 68(1): 55-78.

Grant D, Michelson G, Oswick C, et al. (2005) Guest editorial: discourse and organizational change. Journal of Organizational Change Management 18(1): 6-15.

Haner U-H (2005) Spaces for creativity and innovation in two established organizations. Creativity and Innovation Management 14(3): 288-298.

Hatch M J (1978) Physical barriers, task characteristics, and interaction activity in research and development firms. Administrative Science Quarterly, 32, 387-399. 
Hitters E and Richards G (2002) The creation and management of cultural clusters. Creativity and Innovation Management 11(4): 234-247.

Kociatkiewicz J and Kostera M (2015) Into the Labyrinth: Tales of Organizational Nomadism. Organization Studies 36(1): 55-71.

Kuhn T (2008) A communicative theory of the firm: Developing an alternative perspective on intra-organizational power and stakeholder relationships. Organization Studies 29(8-9): 1227-1254.

Kuhn T and Burk NR (2014) Spatial design as sociomaterial practice. In: Cooren F, Vaara E, Langley A, et al. (eds.), Language and Communication at Work, Oxford University Press, pp. 146-172.

Latour B (1986a) Technology is Society Made Durable. In: Grint K (ed.), Work and Society: A Reader, Polity Press, pp. 41-53.

Latour B (1986b) The Powers of Association. In: Law J (ed.), Power, action and belief: a new sociology of knowledge?, Routledge, pp. 264-280.

Latour B (2005) Reassembling the Social: An Introduction to Actor-Network-Theory. Oxford: Oxford University Press.

Lefebvre H (1991) The Production of Space. Oxford: Blackwell.

Leonardi PM (2011) When flexible routines meet flexible technologies: affordance, constraint, and the imbrication of human and material agencies. MIS Quarterly 35(1): 147-168.

Macbeth D (2001) On "Reflexivity” in Qualitative Research: Two Readings, and a Third. Qualitative Inquiry 7(1): 35-68.

Manning PK and Van Maanen J (1978) Policing: a view from the street. New York: Random House. 
Martine T, Cooren F and Bartels G (2017) Evaluating Creativity Through the Degrees of Solidity of Its Assessment: A Relational Approach. The Journal of Creative Behavior 0(0): 1-16.

Massey D (2003) Some times of space. In: May S (ed.), Olafur Eliasson: The Weather Project. London: Tate Modern.

McPhee RD (2004) Text, Agency, and organization in the light of structuration theory. Organization 11(3): 355-371.

McPhee RD and Zaug P (2000) The communicative constitution of organizations: A framework for explanation. Electronic Journal of Communication 10(1-2): 1-17.

Moeran B (2009) From participant observation to observant participation. In: Ybema S, Yanow D, Wels H, Kamsteeg F (eds.), Organizational Ethnography: Studying the Complexity of Everyday Life. Newcastle: Sage.

Mould O and Comunian R (2015) Hung, drawn and cultural quartered: rethinking cultural quarter development policy in the UK. European Planning Studies 23(12): 2356-2369.

Musterd S and Murie A (2011) Making Competitive Cities. New York: Wiley.

Nagle R (2013) Picking Up: On the Streets and Behind the Trucks with the Sanitation Workers of New York City. 1 edition. New York: Farrar, Straus and Giroux.

Nicolini D (2009) Zooming in and zooming out: A package of method and theory to study work practices. In: Ybema S, Yanow D, Wels H, et al. (eds.), Organizational Ethnography: Studying the Complexity of Everyday Life, Thousand Oaks, CA: Sage, pp. 120-138.

Nicolini D (2011) Practice as the Site of Knowing: Insights from the Field of Telemedicine. Organization Science 22(3): 602-620.

Nicolini D (2012) Practice Theory, Work, and Organization: An Introduction. Oxford: Oxford University Press. 
O'Connor J (2010) The cultural and creative industries: a literature review. Newcastle upon Tyne: Creativity, Culture and Education.

Ojala S and Pyöriä P (2017) Mobile knowledge workers and traditional mobile workers: Assessing the prevalence of multi-locational work in Europe. ABS Sociologica: 0001699317722593. Ozkil AG, Fan Z, Dawids S, et al. (2009) Service robots for hospitals: A case study of transportation tasks in a hospital. In: 2009 IEEE International Conference on Automation and Logistics, August 2009, pp. 289-294.

Pauwels C, Clarysse B, Wright M, et al. (2016) Understanding a new generation incubation model: The accelerator. Technovation, 50-51: 13-24.

Peck J (2012) Recreative City: Amsterdam, vehicular ideas and the adaptive spaces of creativity policy. International Journal of Urban and Regional Research 36(3): 462-485.

Phillips, J (2006) Agencement/Assemblage. Theory, Culture \& Society 23(2-3): 108-109.

Pittinsky TL and Shih MJ (2004) Knowledge Nomads: Organizational Commitment and Worker Mobility in Positive Perspective. American Behavioral Scientist 47(6): 791-807.

Putnam LL (2015) Unpacking the Dialectic: Alternative Views on the Discourse-Materiality Relationship. Journal of Management Studies 52(5): 706-716.

Putnam LL and Fairhurst GT (2015) Revisiting “Organizations as Discursive Constructions": 10 Years Later. Communication Theory 25(4): 375-392.

Quattrone P (2004) Accounting for God: accounting and accountability practices in the Society of Jesus (Italy, XVI-XVII centuries). Accounting, Organizations and Society 29(7): 647683.

Riach K and Wilson F (2014) Bodyspace at the pub: Sexual orientations and organizational space. Organization 21(3): 329-345. 
Richardson L (2000) Writing: A method of inquiry. In: Lincoln YS and Denzin NK (eds.), Handbook of Qualitative Research, Thousand Oaks, CA: Sage, pp. 923-948.

Schatzki TR (2005) Peripheral Vision: The Sites of Organizations. Organization Studies 26(3): $465-484$.

Schoeneborn D (2011) Organization as communication: A Luhmannian perspective. Management Communication Quarterly 25(4): 663-689.

Schoeneborn D (2013) The pervasive power of PowerPoint: How a genre of professional communication permeates organizational communication. Organization Studies 34(12): $1777-1801$.

Schoeneborn D, Blaschke S, Cooren F, et al. (2014) The three schools of CCO thinking: Interactive dialogue and systematic comparison. Management Communication Quarterly 28(2): $285-316$.

Sihvonen T and Cnossen B (2015) Not only a workplace. Reshaping creative work and urban space. Observatorio $\left(O B S^{*}\right)$ 9(5): 47-69.

Sillince JAA (2009) Can CCO theory tell us how organizing is distinct from markets, networking, belonging to a community, or supporting a social movement? Management Communication Quarterly 24(1): 132-138.

Smith C and Anderson L (2018) Fitting Stories: Outreach Worker Strategies for Housing Homeless Clients. Journal of Contemporary Ethnography: 0891241618760982.

Stouten J, Rousseau DM and De Cremer D (2018) Successful Organizational Change: Implementing the Management Practice and Scholarly Literatures. Academy of Management Annals, in press. 
Sturdy A, Handley K, Clark T, et al. (2009) Management consultancy: Boundaries and knowledge in action. New York: Oxford University Press.

Suddaby R and Foster WM (2017) History and Organizational Change. Journal of Management 43(1): 19-38.

Sutton D, Helstosky C and Cwiertka KJ (2004) Thoughts Towards an Ethnography of Restaurants. Food and Foodways 12(1): 53-67.

Taylor JR and Van Every EJ (2000) The Emergent Organization: Communication as Its Site and Surface. Mahwah, N.J.: Lawrence Erlbaum Associates.

Taylor S and Spicer, A (2007) Time for space. A narrative review of research on organisational spaces. International Journal of Management Reviews 9(4): 325-346.

Thrift N (1999) Steps to an ecology of place. In: Massey D, Allen J, and Sarre P (eds.), Human Geography Today, Cambridge, UK: Polity Press, pp. 295-322.

Tsoukas H and Chia R (2002) On organizational becoming: Rethinking organizational change. Organization Science 13(5): 567-582.

Tyler M and Cohen L (2010) Spaces that matter: Gender performativity and organizational space. Organization Studies 31(2): 175-198.

Valli, C (2015) When cultural workers become an urban social movement: Political subjectification and alternative cultural production in the Macao movement, Milan. Environment and Planning A 47(3): 643-659.

Van Maanen J (1988) Tales of the field: on writing ethnography. Chicago guides to writing, editing, and publishing, Chicago: University of Chicago Press.

Vásquez C (2016) A spatial grammar of organising: studying the communicative constitution of organisational spaces. Communication Research and Practice 2(3): 351-377. 
Vásquez C and Cooren F (2013) Spacing practices: The communicative configuration of organizing through space-times. Communication Theory 23(1): 25-47.

Vásquez C, Bencherki N, Cooren F, et al. (2017) From 'matters of concern' to 'matters of authority': Reflecting on the performativity of strategy in writing a strategic plan. LongRange Planning.

Venn, C (2006) A Note on Assemblage. Theory, Culture \& Society 23 (2-3): 107-108.

Vismann C (2008) Files: law and media technology. Stanford, CA: Stanford University Press.

Wasserman V and Frenkel M (2015) Spatial work in between glass ceilings and glass walls: Gender-class intersectionality and organizational aesthetics. Organization Studies 36(11), 1485-1505.

Wilhoit ED (2016) Ventriloquism's methodological scope. Language Under Discussion 2(1): 45-49.

Yaneva A (2009) The Making of a Building: A Pragmatist Approach to Architecture. London: Peter Lang.

Yanow D (1995) Built Space as Story. Policy Studies Journal 23(3): 407-422.

Yanow D (1998) Space stories: studying museum buildings as organizational spaces while reflecting on interpretive methods and their narration. Journal of Management Inquiry, 7: 215-239.

Ybema S and Kamsteeg FH (2009) Making the familiar strange: A case for disengaged organizational ethnography. In: Ybema S, Yanow D, Wels H, et al. (eds.), Organizational Ethnography: Studying the Complexities of Everyday Life, Thousand Oaks, CA: Sage, pp. $101-119$. 
Zemel A and Koschmann T (2016) A stitch in time: Instructing temporality in the operating room. Communication \& Medicine 12(1): 85-98.

Zundel M, Holt R and Cornelissen J (2013) Institutional work in The Wire: An ethological investigation of flexibility in organizational adaptation. Journal of Management Inquiry 22(1): 102-120. 
Table 1: Examples of the mutual constitution of organizing and space

\begin{tabular}{|c|c|c|c|c|}
\hline \multirow[b]{2}{*}{ 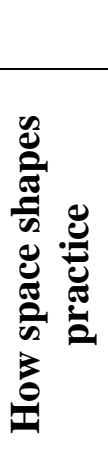 } & \multicolumn{2}{|c|}{ Relaunch } & \multicolumn{2}{|c|}{$\mathbf{A B S}$} \\
\hline & $\begin{array}{l}\text { A centrally- } \\
\text { located trailer } \\
\text { serves as a } \\
\text { meeting point } \\
\text { and café. }\end{array}$ & $\begin{array}{l}\text { The regular layout } \\
\text { of the containers in } \\
\text { the large warehouse } \\
\text { means that each } \\
\text { tenant has both a } \\
\text { container and a lot } \\
\text { on the negative } \\
\text { space next to it. }\end{array}$ & $\begin{array}{l}\text { The building's } \\
\text { asbestos } \\
\text { contamination forced } \\
\text { it to open in two } \\
\text { phases, creating a } \\
\text { distinction between } \\
\text { tenants. }\end{array}$ & $\begin{array}{l}\text { Being old and } \\
\text { somewhat decrepit, } \\
\text { the building } \\
\text { regularly needs } \\
\text { repairs and } \\
\text { maintenance work. }\end{array}$ \\
\hline 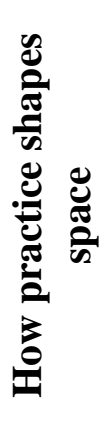 & $\begin{array}{l}\text { People have the } \\
\text { habit of visiting } \\
\text { the centrally } \\
\text { positioned trailer } \\
\text { to grab a coffee, } \\
\text { listen to music, } \\
\text { and take } \\
\text { advantage of } \\
\text { heating. }\end{array}$ & $\begin{array}{l}\text { Shipping containers } \\
\text { serve as storage and } \\
\text { office space, while } \\
\text { the lot usually serves } \\
\text { as a workspace. } \\
\text { People trade their } \\
\text { extra storage space } \\
\text { to their neighbours. }\end{array}$ & $\begin{array}{l}\text { The chicken, initiated } \\
\text { by Ronald, becomes a } \\
\text { collective project to } \\
\text { create continuity } \\
\text { through the buildings } \\
\text { various areas. Borrols } \\
\text { allow tenants to } \\
\text { discover their building } \\
\text { and each other's work. }\end{array}$ & $\begin{array}{l}\text { Music and sound } \\
\text { artists soundproof } \\
\text { their studios. } \\
\text { Residents request } \\
\text { and accomplish the } \\
\text { maintenance work } \\
\text { that needs to be } \\
\text { done. Artists trade } \\
\text { leftover material. }\end{array}$ \\
\hline 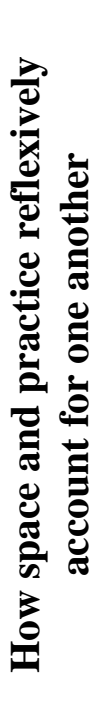 & \multicolumn{2}{|c|}{$\begin{array}{l}\text { The containers make practice possible } \\
\text { and are defined by practice: taking } \\
\text { advantage of the café, storing material } \\
\text { in the containers, working on the lots, } \\
\text { etc. The containers' relative location } \\
\text { creates a communal area at the centre } \\
\text { where the café trailer is placed, } \\
\text { delineates lots where people work and } \\
\text { creates a "neutral" zone where meetings } \\
\text { are held. That is why reassembling the } \\
\text { containers and other artefacts in similar } \\
\text { ways allows recreating the collective's } \\
\text { social configuration in the new } \\
\text { warehouse. }\end{array}$} & \multicolumn{2}{|c|}{$\begin{array}{l}\text { The building's separation in two phases } \\
\text { makes impromptu encounters difficult, but } \\
\text { tenants organize social activities, such as } \\
\text { borrols, and value elements like the chicken, } \\
\text { which they reproduce across the building to } \\
\text { create continuity throughout its parts and } \\
\text { meaningfully assemble them into a coherent } \\
\text { whole. These practices at once take advantage } \\
\text { of the building's intricate corridors and give } \\
\text { them a collective meaning. The building's } \\
\text { exiguous rooms and many corners contribute } \\
\text { to an economy of sharing and maintaining } \\
\text { that reinforces the need to collaborate and } \\
\text { invites tenants to creatively improve the } \\
\text { building (e.g., the book swap corner). }\end{array}$} \\
\hline
\end{tabular}




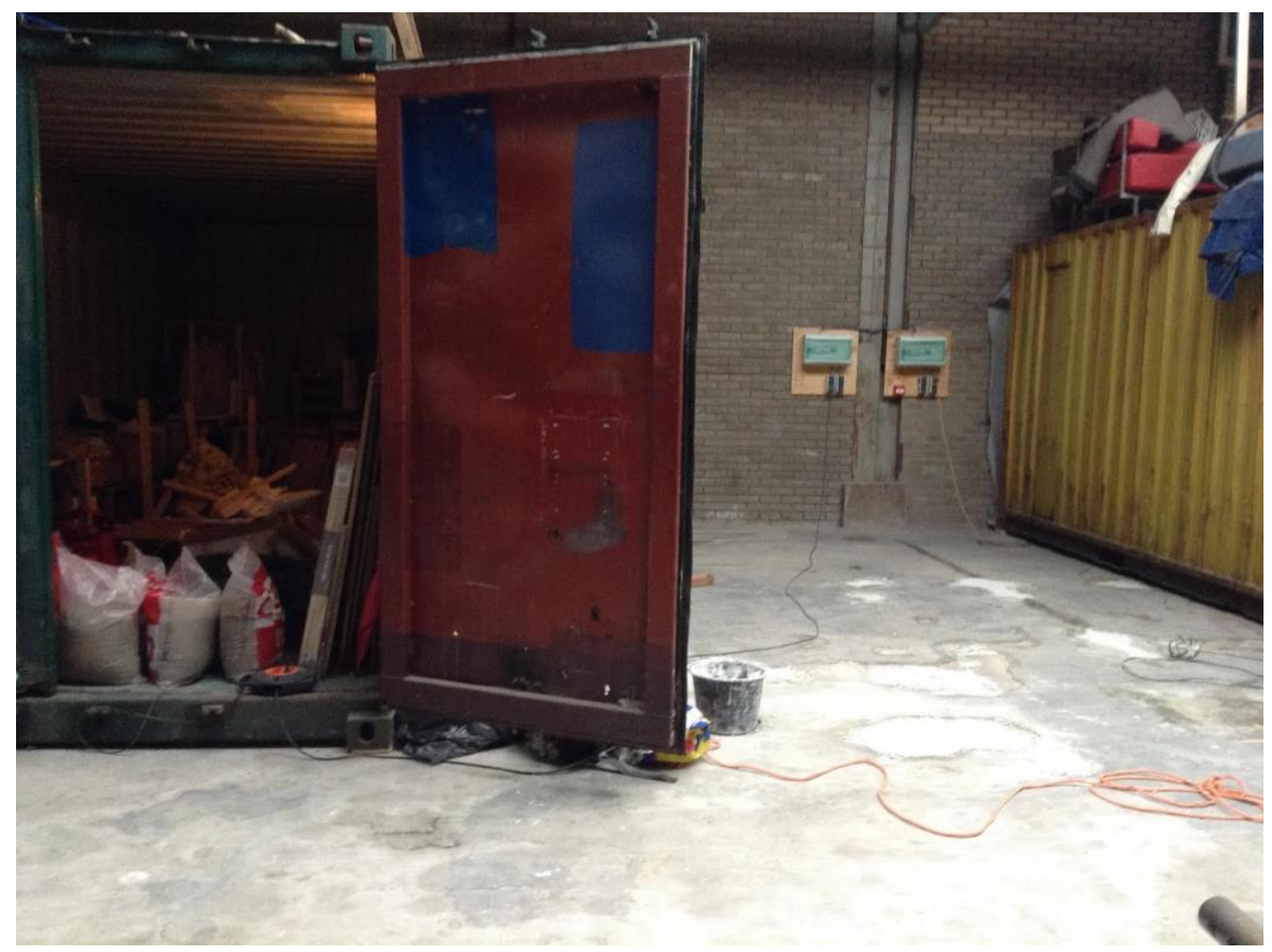

Figure 1. The containers, and the negative space between them, in the new warehouse right after the move.

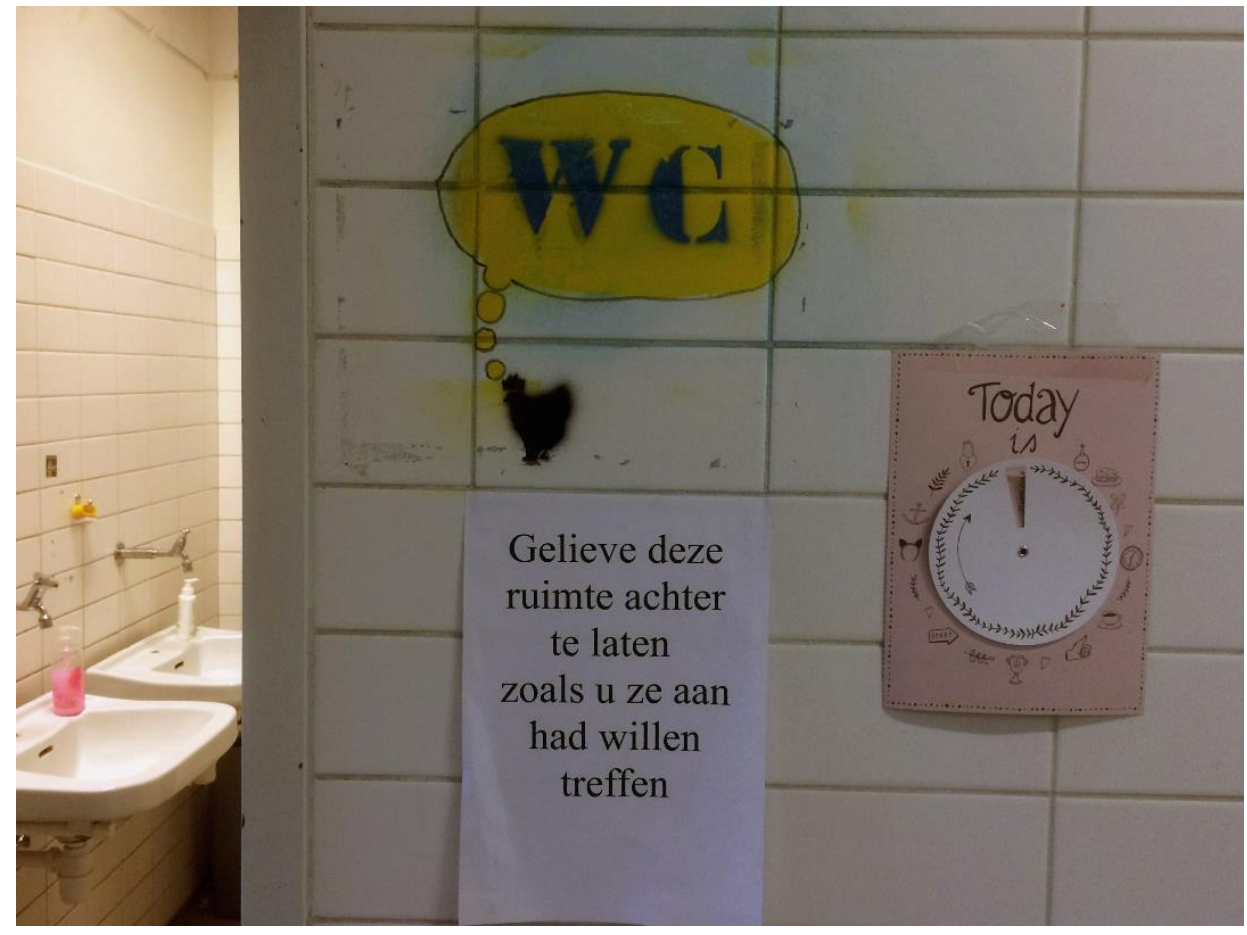

Figure 2. A spray-painted chicken in the 'phase 1' section. 


\section{Appendix 1. Index of interviewees}

Interviewee 1, male furniture designer from the Netherlands, affiliated with Relaunch.

Interviewee 2, female multimedia artist from the Netherlands, affiliated with ABS.

Interviewee 3, male multimedia and performance artist from Taiwan, affiliated with ABS.

Interviewee 4, female visual artist from Poland, affiliated with ABS.

Interviewee 5, male architect from Russia, affiliated with ABS. 